\title{
emeraldinsight
}

\section{Personnel Review}

Human Resource flexibility and performance in the hotel industry: the role of organizational ambidexterity

Mercedes Úbeda-García, Enrique Claver-Cortés, Bartolomé Marco-Lajara, Patrocinio Zaragoza-Sáez,

\section{Article information:}

To cite this document:

Mercedes Úbeda-García, Enrique Claver-Cortés, Bartolomé Marco-Lajara, Patrocinio Zaragoza-Sáez, (2017) "Human

Resource flexibility and performance in the hotel industry: the role of organizational ambidexterity", Personnel Review, Vol.

46 Issue: 4, doi: 10.1108/PR-12-2015-0315

Permanent link to this document:

http://dx.doi.org/10.1108/PR-12-2015-0315

Downloaded on: 14 April 2017, At: 23:52 (PT)

References: this document contains references to 0 other documents.

To copy this document: permissions@emeraldinsight.com

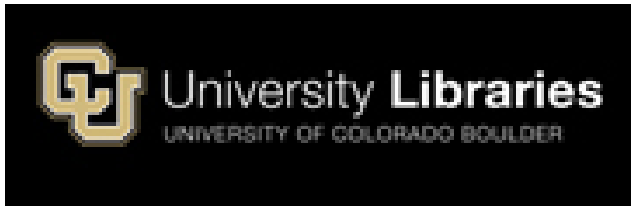

Access to this document was granted through an Emerald subscription provided by emerald-srm:374341 []

\section{For Authors}

If you would like to write for this, or any other Emerald publication, then please use our Emerald for Authors service information about how to choose which publication to write for and submission guidelines are available for all. Please visit www. emeral dinsight. com/ authors for more information.

\section{About Emerald www.emeraldinsight.com}

Emerald is a global publisher linking research and practice to the benefit of society. The company manages a portfolio of more than 290 journals and over 2,350 books and book series volumes, as well as providing an extensive range of online products and additional customer resources and services.

Emerald is both COUNTER 4 and TRANSFER compliant. The organization is a partner of the Committee on Publication Ethics (COPE) and also works with Portico and the LOCKSS initiative for digital archive preservation.

*Related content and download information correct at time of download. 


\section{Human Resource flexibility and performance in the hotel industry: the role of organizational ambidexterity}

Purpose -The purpose of this paper is to explore if human resource flexibility (HR flexibility) facilitates the development of organizational ambidexterity, which in turn has positive effects on firm performance.

Design/methodology/approach - The research hypotheses are tested by partial least squares (PLS) with data from a sample of 100 Spanish hotels.

Findings - The results confirm a total mediator effect of organizational ambidexterity on the relationship between HR flexibility and performance. However, it was not possible for us to check that such flexibility directly influences performance. This may be due to the fact that human resource flexibility has a gradual effect on the development of organizational ambidexterity.

Research limitations/implications - The results of this study contribute to the knowledge on the impact of human resource flexibility on performance. This paper thus stresses the strategic role that human resources play within organizations, insofar as their flexibility makes it possible to develop a highly relevant organizational capability such as ambidexterity. The study's limitations are the analysis technique utilized (it assumes linearity between latent variables) and that the research only explores the hotel industry.

Practical implications - Human resource managers need to consider that HR flexibility contributes to developing organizational ambidexterity and the ability to combine the learning of exploration and exploitation affects the firm's performance and, therefore its competitiveness. 
Originality/value - The results of this study can contribute to broaden the knowledge about the impact of human resource flexibility on performance. In fact, the studies on HR flexibility performed so far have focused on analyzing the role played by that flexibility as a mediator variable between high performance work system (HPWS) and performance. This work goes one step further, trying to examine the extent to which human resource flexibility influences the ability to undertake exploitation and exploration processes at the same time. This paper thus stresses the strategic role that human resources play within organizations, insofar as their flexibility makes it possible to develop a highly relevant organizational capability as is ambidexterity.

Keywords Organizational Ambidexterity; Human Resource Flexibility; Firm Performance

Paper type Research paper

\section{Introduction}

Two topics have been at the foreground of human resource management studies in recent years. The first is the utilization of high commitment and/or high performance work systems -HPWS- (Arthur, 1994; Pfeffer, 1994; Sanders, Shipton, and Gomes, 2014) by organizations, whereas the second focuses on the forms of organization that can provide firms with workforce flexibility (Kalleberg, 2001, 2003; Vela-Jimenez et al., 2014; De Lastra et al., 2014; Natasaputra and Kusumastuti, 2016). Labour flexibility is a very important topic in every organization, but even more so within highly labour-intensive sectors strongly affected by seasonality, as is the case of the hotel industry (Knox and Walsh 2005; Hoque, 2013; Duncan, Scott and Baum 2013; Yaduma et al., 2015).

The combination of these two characteristics makes the hotel industry of special interest when it comes to studying human resource flexibility. This has been of great concern within 
the Spanish tourism sector lately. Labour flexibility is often understood in an incorrect and incomplete way, since it exclusively refers to the use of work contracts with a fixed duration or focuses on the reduction of redundancy costs. In fact, one of the main problems faced by the hotel industry is the high staff turnover derived from its partially understood labour flexibility.

Furthermore, the development recently experienced by the notion of organizational ambidexterity offers a new perspective from which different organizational aspects -amongst them, human resource management- can be analysed (Glaister, Ahammad and Junni, 2015; Patel et al., 2013; Prieto and Santana, 2012; Kang and Snell, 2009)

Even though progress has been made in research on human resource flexibility and organizational ambidexterity, no works relating both concepts have been written so far. Nevertheless, these topics raise a number of questions such as: Does human resource flexibility influence the development of the ambidextrous learning capacity? Does human resource flexibility have an impact on organizational performance? Is organizational ambidexterity positively related to business results? Does organizational ambidexterity mediate between human resource flexibility and performance? The search for answers to these questions is what led us to write the present paper and a sample of Spanish hotels is utilized to this end. Our choice of this industry is due to its great interest in the issue of human resource flexibility and the fact that the ability to exploit knowledge (in order to be efficient and competitive via prices) no longer suffices; the need arises for hotels to simultaneously develop the capacity to explore new knowledge (seeking to innovate and offer differential services with respect to competitors).

\section{Organizational ambidexterity}


The bibliography dedicated to organizational ambidexterity has tended to revolve around how to achieve balance and simultaneity between exploration-based and exploitation-based learning. Several options have been suggested in the bibliography. The first is known as structural, partitional or reciprocal ambidexterity (Gibson and Birkinshaw, 2004; Simsek et al., 2009; Raish and Birkinshaw, 2008; Chebbi et al., 2015). This sort of ambidexterity achieves a combination between both types of learning through the creation of structural mechanisms that make possible either the alternation between exploitation and exploration periods or the coincidence in time between both types of learning, though in various organizational units with different structural configurations.

Another alternative regards organizational ambidexterity as a capacity of leaders (Gibson and Birkinshaw, 2004; Mom et al., 2009; Zimmermann, Raisch and Birkinshaw, 2015). From this perspective, ambidexterity would be achieved if executives' behaviour is oriented towards the combination of exploratory and exploitative activities.

Finally, there is contextual or harmonic contextual ambidexterity (Simsek et al., 2009; Hahn et al., 2016), which arises when the organization designs social and behavioural mechanisms which allow employees to follow both types of learning (Prieto and Santana, 2012). This perspective establishes the importance of building a specific organizational context which allows and encourages individuals to think for themselves about how to better divide their time between the conflicting demands for exploitation and exploration. As stressed by Kang and Snell (2004) and Ahammad et al. (2015), contextual ambidexterity assumes that the ambidexterity of an organization as a whole derives from specific actions carried out by individuals; in other words, it is indissolubly linked to the firm's efforts to manage its human resources. 
Therefore, organizations which pursue ambidextrous behaviour should develop the functional aspect of their human resources so that they can devote their efforts to activities associated with both exploitation and with exploration (Cordery et al., 1993; Lepak et al., 2003). The expression 'human resource flexibility' consequently appears as an antecedent variable of organizational ambidexterity.

\section{Human resource flexibility}

Within the strategic approach to human resource management, researchers have advocated flexibility in human resource systems and processes to help the organization adapt to a complex and dynamic environment (Lengnick-Hall and Lengnick-Hall, 1988; Snow and Snell, 1993; Ketkar and Sett, 2009; Way et al., 2012; Camps et al., 2015). From this point of view, human resource flexibility is conceived as a capability through which the organization can more easily adapt to environmental contingency changes (Snell, Youndt, and Wright, 1996; Tracey, 2012; Camps et al., 2015 Sekhar, Patwardhan and Vyas, 2016), where both intangible assets, such as knowledge and other tangible ones, play a role in the determination of competitive advantage (Hitt et al. 2001; Miller and Lee, 2001; Sirmon, Hitt and Ireland, 2007; Aryee et al., 2016). In the words of Wright and Snell (1998), employees' flexibility can be defined as the extent to which the firm's human resources possess skills and behaviour repertoires which offer the organization a chance to develop strategic alternatives within its competitive environment.

Focusing on the concept of human resource flexibility, the literature draws a distinction between external or numerical flexibility and internal or functional flexibility (Atkinson, 1984; Michie and Sheehan, 2005; Kumari and Pradhan, 2014). Numerical flexibility refers to a firm's ability to vary the amount of labour employed, while functional flexibility is associated with the ability to perform a variety of heterogeneous tasks. 
This research sees organizational ambidexterity as the final variable promoted by internal flexibility; in other words, internal flexibility does not constitute an end in itself but a means to develop organizational capabilities (Lado and Wilson, 1994; Shafer et al., 2001; Aagaard and Andersen 2014), among which would stand out ambidexterity or the ability to undertake exploratory and exploitative learning at the same time (Jerez-Gomez et al., 2005; Camps et al., 2015). Exploratory learning presupposes the search for new knowledge to create new customer value or to replace a firm's present knowledge with the aim of improving current customer value. Exploitative learning seeks to refine existing knowledge so that current customer value can be expanded or improved (March, 1991; Gupta et al., 2006; Turner, Swart and Maylor 2013). Organizational ambidexterity suggests that a firm needs both types of learning and also that they can be promoted through the adoption of various flexibility forms (López-Cabrales et al., 2011).

Even though human resource flexibility has been traditionally presented as a desirable capability in the aforesaid works, its dimensions as well as the process through which it develops were not adequately studied until Wright and Snell (1998) described these conceptualization deficiencies around the following three dimensions: skill flexibility; behavioural flexibility; and HR practice flexibility.

The definition of behavioural flexibility by Wright and Snell (1998) gives the consideration of 'behaviour' at work to those routine scripts or sequences that employees follow when performing their tasks. For these authors, behaviours become rigid or inflexible when the employees who have applied a sequence of actions to handle repetitive situations select the same sequence to deal with new situations. By contrast, if employees are capable of using different routines when faced with new circumstances, their behaviours are flexible. Expressed differently, employees with flexible behaviours adapt their responses to previously unknown circumstances on the basis of improvisation rather than following predefined action 
patterns (Wright and Snell, 1998; Bhattacharya et al., 2005; Dyer and Ericksen, 2005; Kumari and Pradhan, 2014;). There is a variety of reasons why flexible behaviours amongst employees constitute a valuable resource for the organization. Firstly, employees who can successfully cope with different contingencies at their workplace allow the firm to achieve savings in the costs derived from the lack of adaptation to change (Lepine et al., 2000). And secondly, behavioural flexibility makes it easier to implement change processes in the firm, insofar as it gives the organization real chances to adequately respond to a wide range of situations (Bhattacharya et al., 2005; Beltrán-Martín and Roca-Puig, 2013).

Skill flexibility arguably differs from behavioural flexibility in the fact that employees may have a motivation to act flexibly but lack the knowledge or skills required to do so. Flexibility in skills is one of the most relevant antecedents of flexibility in behaviours (Sujan et al., 1994). Following the suggestion of Wright and Snell (1998), Beltrán-Martín (2008) and Kumari and Pradhan (2014), skill flexibility refers on the one hand to the number of potential alternative uses where the knowledge and skills owned by an employee can be applied. Those who have acquired a large number of skills which allow them to perform a wide range of tasks are flexible employees. A flexible employee is thus one who shows the ability to work on different tasks and under various circumstances, a low cost and a short period of time being required to mobilize this employee to new functions or jobs (Riley and Lockwood, 1997; Van den Berg and Van der Velde, 2005; De Lastra et al., 2014; Camps et al., 2015). And on the other hand, skill flexibility is also related to the ability of employees to develop a broad variety of skills in the future (Wright and Snell, 1998; Maurer et al., 2003; Martin et al., 2013). Flexible employees are trained and recycled according to necessity; they anticipate the needs for future skills, show enthusiasm about learning new approaches to tasks, and perceive each event occurring inside the organization as a way to learn something 
important for the future (Arulampalam and Booth, 1998; Kohli et al., 1998; Pulakos et al., 2000; Dyer and Ericksen, 2005; Chang et al., 2013; Stokes et al., 2015).

Human resource management practice flexibility is the degree to which such practices can be adapted and applied to a variety of situations or in diverse units or sections of the organization, as well as the speed at which these adaptations and applications take place (Bhattacharya et al., 2005; Beltrán-Matín et al., 2008; Kumari and Pradhan, 2014). It could be said that it is the firm's ability to implement/apply alternative human resource practices easily and effectively. Flexibility in practices may create value inside the organization in several ways. Firstly, when the firm's situation undergoes changes, the organization can change its practices quickly. For instance, a remuneration system based on the description of jobs is bound to create resistance to change; however, a flexible pay policy linked to profit measures adapts faster to changes in terms of profit increase or decrease (Milkovich and Newman, 1999; Ismail et al., 2015). Secondly, flexibility in human resource practices will most probably result in flexible behaviours amongst employees. In the previous example about variable compensation plans, it becomes easier for employees to adapt to the change required by the business because their remuneration is determined by the firm's success. And thirdly, human resource practice flexibility enables the firm to offer similar practices in different units and to achieve coherence throughout the organization.

In our opinion, the flexibility of human resources (understood as the conjunction of flexibility in behaviours, skills, and human resource practices) will have a positive effect on organizational ambidexterity, insofar as it facilitates the possession of skills and behaviour repertoires on the part of employees, thanks to which they can exploit and explore new strategic alternatives; hence our proposal of the following hypothesis.

Hypothesis 1. HR flexibility is positively related to organizational ambidexterity 
As for the connection between human resource flexibility and performance, several studies have shown that employees' flexibility affects business results (Way et al., 2013; Arabi and Daneshparvar, 2008; Chang et al., 2013; Way et al., 2013; Preenen et al., 2015). By way of example, works placed within the framework of the human capital theory argue that the set of capabilities and skills underlying flexibility in human resources determines their capacity to be responsible for several activities inside the organization (Rönnmar, 2004; Camps et al., 2015). Employees with a broad knowledge base contribute to the organization's competitive advantage because this base generates higher capabilities to develop more efficient means to fulfil the different task requirements (Wright et al., 1994; Boxall, 1999; Boxall, 2013). A number of studies assume that greater flexibility increases employees' level of satisfaction and motivation and, accordingly, their productivity (Cordery et al., 1993 Camps et al., 2015). Moreover, flexible employees maintain profitable relationships with customers that contribute to meeting those customers' needs, as well as to improving their satisfaction levels (Youndt and Snell, 2004; Fu et al., 2015).

Human resource flexibility may become relevant in the adoption of innovative solutions inside the firm because such flexibility implies that employees can better respond to stimuli which have previously appeared. To this must be added that, when employees improve their knowledge base on a regular basis, their performance variability at work decreases and, consequently, their productivity increases (Lado and Wilson, 1994; Nieves and Quintana, 2016). Similarly, flexibility encourages the members of an organization to improvise and come up with new ideas, to question themselves and reflect on their actions, to give sense and generate new knowledge from these actions. For instance, it allows organization members to think about ways to reduce costs and develop new innovations in service delivery (Youndt and Snell, 2004; Nieves and Quintana, 2016). Some empirical studies have provided evidence of the impact that such a flexible employee has on working performance (Crant, 1995; 
Glaser, Stam and Takeuchi, 2015), on job satisfaction (Seibert, Crant, and Kraimer, 1999; Glaser, Stam and Takeuchi, 2015), on productivity, on customer service, and on the degree of commitment to the organization (Kirkman and Rosen, 1999; Beltrán-Martín et al., 2008, 2013; Camps et al., 2015), as well as on objective financial performance measures (Bhattacharya et al., 2005; Ngo and Loi, 2008) and on subjective financial performance measures (Ketkar and Sett, 2009, 2010). This leads us to propose the following hypothesis:

\section{Hypothesis 2. Human resource flexibility is positively related to performance}

Focusing on the relationship between organizational ambidexterity and performance; although some researchers have shown that organizational ambidexterity directly affects performance (for example, Gibson and Birkinshaw, 2004; Lubatkin et al., 2006), others have identified this relationship as being contingent (Lin et al., 2007; Cao, Gedajlovic and Zhang, 2009; Mom, Fourné and Jansen, 2015), and there are even studies which have found negative effects (He and Wong, 2004; Atuahene-Gima, 2005; Lavie, Kang and Rosenkopf, 2011), and there are even studies that show an inverted $U$ shaped relationship between ambidexterity and performance (Caspin-Wagner, Ellis and Tishler, 2012; Wei, Zhao and Zhang, 2014). Thus, the question as to whether or not -and in which conditions- ambidexterity leads to improved performance is still scarcely developed and even contradictory results exist. For this reason, our paper attempts to confirm that ambidexterity positively influences the organization's results through the formulation of the hypothesis offered below.

\section{Hypothesis 3. Organizational ambidexterity is positively related to performance}

Finally, as explained earlier, the present work seeks to verify if organizational ambidexterity acts as a mediator variable between human resource flexibility and performance. The following hypothesis is proposed to that end: 
Hypothesis 4. The effect of HR flexibility on firm performance is mediated by organizational ambidexterity

\section{Research Methods}

Data collection and processing

Both the theoretical model and the hypotheses proposed were tested using a sample of Spanish hotels. Our analysis focused on hotels with three or more stars located in the Valencian Autonomous Region (Spain). More precisely, the population under study comprised a total of 415 establishments included in various databases (amongst others, the municipal tourism supply, Turespaña, or the Iberian Balance Sheet Analysis System -SABI for its initials in Spanish).

A questionnaire addressed to HR managers was designed for the purpose of obtaining all the necessary information. Two reasons led us to choose these addressees; firstly because they had enough knowledge about the items covered in the research; and secondly, because they were committed to our study object. A consensus was previously reached on the questionnaire with experts in human resource management, as well as with tourism sector professionals. A pre-test carried out with 15 hotels allowed us to define the questions that were ultimately included in the questionnaire. The validated questionnaire was sent online. The assurance of information confidentiality and interviewee anonymity served to increase the response rate. A total of 100 questionnaires considered valid were collected (after sending three reminders to non-responders), which covered $24.1 \%$ of the population under study, with a sampling error of $8.5 \%$ at $95.5 \%$. The sampling error turned out to be relatively high, but this often happens in research works carried out in Spain, where collaboration between firms and universities is not easily established (Camelo et al., 2004). To test for non-responses bias, we examined differences between respondents and non-respondents. T-test showed no significant differences based on control variables (size and category). 


\section{Measurement}

All the items used to measure the variables shown below are listed in Appendix 1.

Ambidexterity. Even though there is no widely accepted measurement of organizational ambidexterity, it is possible to find solid research works in the literature which allow us to establish a measurement for this variable. For instance, the studies of Chang, Hughes, and Hotho (2011), Gibson and Birkinshaw (2004), Gupta et al., (2006), and Jansen et al. (2005, 2006, 2009), use scales to measure organizational ambidexterity in service companies. In the present study we use the exploitation and exploration scales developed by Jansen et al. (2006 and 2009) and Stettner and Lavie (2014) adapting them to our study population, and treating the two scales as orthogonal variables (Gibson and Birkinshaw, 2004, Jansen et al., 2009). Ambidexterity thus appears in our work as a latent construct which captures the co-variance of both innovation types. A factor analysis with varimax rotation reveals the two-factor structure, which accounts for $71.95 \%$ of variance -these two factors adequately represent the exploration and exploitation elements. Reliability can be considered suitable for both exploration $(\alpha=0.768)$ and exploitation $(\alpha=0.892)$. According to the postulates of Floyd and Lane (2000), these two orientations are 'inseparable' and researchers have combined both measures for the purpose of creating a measurement for organizational ambidexterity.

HR Flexibility. Employees' flexibility is assessed through the measurement scales proposed by Volverda (1998), Verdú (2002), Bhattacharya et al. (2005), Beltrán-Martín et al. (2008) and Beltran-Martin and Roca-Puig (2013). As with the previous variable, a factor analysis provides us with 3 factors that explain $84.89 \%$ of variance. These three factors suitably represent the elements of behavioural flexibility (BF), skill flexibility (SF), and (human resource) practice flexibility $(\mathrm{PF})$. Reliability can be regarded as adequate for both $\mathrm{BF}(\alpha$ $=0.972)$ and for SF $(\alpha=0.938)$, as well as for PF $(\alpha=0.976)$. The combination of these three 
orientations -considered inseparable here- creates the measurement for human resource flexibility.

Performance. Numerous studies have confirmed that perception measurements constitute quite a valid representation of organizational performance (Ngo et al., 1998; Khatri 2000; Hartog and Verburg, 2004). Our study utilizes perception measurements to capture organizational performance on the basis of works such as those written by Gibson and Birkinshaw (2004), Chang and Hughes (2012) or Wang and Rafiq (2014). More specifically, eight items were used to capture general performance criteria (market share growth, brand recognition, market image of the firm, and sales growth) on the one hand; and performance variables better suited to hotel sector firms (revenues per room, average occupancy, customers' satisfaction level, and employees' satisfaction) on the other. Interviewees were asked to specify the average perceived performance for each variable -with respect to their competitors- corresponding to the last three years. It was deemed appropriate for us to establish a minimum period of three years since the results of certain organizational capabilities -such as ambidexterity and human resource flexibility in our study- which are generated with time periods exceeding a financial year (Wright, Dunford and Snell, 2001). As with the preceding scales, a factor analysis serves to check scale unidimensionality. Indeed, a single factor appeared which explains $77.642 \%$ of variance. Cronbach's $\alpha$ is 0.959 .

Our study also monitors possible alternative explanations for the relationships set forth in the theoretical model through the inclusion of two relevant control variables, namely: hotel size and hotel category. Firstly, because large organizations are likely to own more resources but they may also lack the flexibility required to be ambidextrous, it was decided to include the number of full-time employees as an indicator of firm size. After all, greater size has traditionally been associated with inertia and difficulty in processing information -both aspects being related to change of resources and the failure to adapt to ever-changing 
conditions (Hannan and Freeman, 1989). Secondly, different studies have shown that the higher the category, the higher the hotel performance levels (Pine and Phillips, 2005; Chand and Katou, 2007); hence our decision to use hotel category as a control variable.

\section{Statistical Procedure}

As a previous step to estimating measurement or structural models, an analysis was carried out for the purpose of examining common method variance, since all the variables included in our research were appraised by a single person within each organization. According to Harman's single factor test (Podsakoff et al., 2003), if common method variance existed, a single factor would emerge from a factor analysis with all research indicators. This test must be preceded by the estimation of a confirmatory factor analysis (CFA) that includes all the indicators from every scale, with a view to determining whether most of the variance in this model is explained by a general factor (Podsakoff et al., 2012). Five factors are identified which explain the $81.36 \%$ of variance. None of the factors explains more than $50 \%$ of variance, which suggests that no common method variance exists in our study, because these indices do not reach the values considered acceptable.

The data analysis method used in this paper -known as Partial Least Squares (PLS)turned out to be the most appropriate when technical knowledge is limited and the model to be estimated has a more complex nature (Chin et al., 2003). This happens in our case, since only few research works relate HR flexibility and ambidexterity; furthermore, this technique is less demanding with regard to the minimum sample size, the nature of measure scales, and the distribution of observable variables -in comparison with the tools of co-variance-based structural equation models such as LISREL or EQS (Chin et al., 2003).

To make the HR flexibility variable operational in the PLS model, we consider a secondorder construct made up of three first-order reflective constructs, namely: behavioural flexibility, skill flexibility and human resource practice flexibility. 
The ambidexterity variable is also regarded here as a second-order construct formed by two first-order reflective constructs known as exploitative innovation and exploratory innovation. Analyses and results

Since PLS does not permit direct representation of second-order factors, the first step to create them is to calculate the factor scores of first-order constructs (latent variable scores), which are subsequently considered the indicators of second-order factors (Chin et al., 2003; Bock et al., 2005). Thus, in a first stage, the first-order factors that HR flexibility and organizational ambidexterity represent are separately included in the model with their respective indicators.

Insert Table 1. Measurement model evaluation

In the second step, a model is estimated which uses the latent variable factor scores calculated in the first step for each of the first-order components. After building the secondorder variables, the measurement model is assessed on the basis of the stages proposed by Hair et al. (2011).

\section{Stage 1. Measurement model evaluation}

The individual reliability of indicators is evaluated through their loadings $(\lambda)$. In this respect, all loadings exceed the value of 0.7 -as recommended in the bibliography (Carmines and Zeller, 1979). This first stage must also include the evaluation of scales through the Cronbach's $\alpha$ and composite reliability (CR) indices -and the existence of convergent validity through the average variance extracted (AVE). As can be observed in Table 1, both the alpha/ $\alpha$ and the CR values exceed the critical 0.7 in all variables, and the AVE value is above 0.5. Finally, measurement model analysis requires verification of the existence of discriminant validity. In this regard, the method most widely accepted in PLS consists in comparing the AVE value of each construct with the squared correlation of the same construct with each of the variables. Therefore, if AVE exceeds the squared correlation, it can 
be accepted that each construct is more closely related to its own measures than to those of other variables (Barclay et al., 1995). Table 2 shows the AVE square root on the diagonal and the correlations estimated for each pair of constructs in the elements outside the diagonal. This information confirms the existence of discriminant validity in such constructs.

Insert Table 2. Measuring instrument: discriminant validity

\section{Stage 2. Structural model analysis}

The second stage consists in evaluating structural model results (see Figure 1). In order to analyse the result of a structural model, it is first necessary to assess the predictive value of endogenous constructs through $\mathrm{R}^{2}$ values. This index varies between the values 0 and 1 , and the closer they are to 1 the greater the explained variance of the variable under analysis. Although no consensus has been reached so far on the minimum level that this index should reach, Falk and Miller (1992) recommend a minimum value of 0.1 . In the present research work, the $R^{2}$ values of endogenous constructs (see Table 4) are significantly higher than the minimum value (the $\mathrm{R}^{2}$ for performance being 0.667 and that of ambidexterity, 0.683 ). Therefore, it can be stated that our model has an adequate predictive power.

\section{Insert Figure 1. Structural model results}

Secondly, it is necessary to analyse the strength of relationships between constructs (path coefficients, $\beta$ ) and their significance, which will jointly allow us to test the hypotheses. The level of significance corresponding to path coefficients $(\beta)$ is obtained by means of a bootstrap procedure with 5,000 sub-samples (Chin, 1998). As can be seen in Table 3, the direct link between HR flexibility and ambidexterity is significant $(\beta=0.827, \mathrm{t}=30.061$, $\mathrm{p}<0.001)$-the same as the one between ambidexterity and performance $(\beta=0.626, t=6.035$, $\mathrm{p}<0.001)$. However, the relationship between $\mathrm{HR}$ flexibility and performance is not significant $(\beta=0.165, \mathrm{t}=1.398)$. As for the specific control variables introduced in the model, neither hotel category nor size show significant coefficient values. 
$\beta$ coefficients prove the relative intensity of statistical relationships. The variance of an endogenous construct explained by another latent variable is determined by the absolute value, which results from multiplying the coefficient $(\beta)$ by the correlation coefficient between both variables. It is suggested that this coefficient has to reach a value of at least 0.2 (see Table 3). Finally, model quality assessment also takes place through the Geisser test $\left(Q^{2}\right)$, which must be above zero $\left(Q^{2}>0\right.$, see Table 4$)$.

Insert Table 3. Hypothesis confirmation

Insert Table 4. Effects on endogenous variables

The $\mathrm{R}^{2}$ corresponding to organizational ambidexterity is 0.683 (Table 4 ) and would be explained by human resource flexibility; Hypothesis 1 -i.e. HR flexibility is positively related to organizational ambidexterity- would thus be confirmed.

The other endogenous variable corresponds to hotel performance. The model proposed accounts for $66.70 \%$ of this variable. More precisely, ambidexterity is the variable that explains performance with the greatest intensity (49.9\%, see Table 4). This result also allows us to confirm Hypothesis 3; in other words, ambidextrous learning in hotels positively impacts on their performance. However, despite accounting for $11.91 \%$ of performance variance, the HR flexibility variable is not statistically significant (see Table 3), which prevents us from accepting Hypothesis 2. As a result, HR flexibility does not have a positive influence on the organization's performance within our research work.

Two causal models are estimated in our study to test the mediator effect of ambidexterity on human resource flexibility and organizational performance (Hypothesis 4). Following Baron and Kenny (1986), one variable acts as a mediator when it fulfils the following three conditions: 1) variations in the independent variable levels significantly affect the variations of the alleged mediator variable; 2) variations in the mediator significantly affect dependent variable variations; and 3) a previously significant relationship between the independent and 
the dependent variable stops being significant, the strongest demonstration of mediation occurring when the direct relationship equals zero. Therefore, our attention focuses on one model where only the direct impact caused by the independent variable (human resource flexibility) on the dependent variable (performance) is considered - Model $1-$ and on another model derived from the theoretical development carried out in the preceding section -Model 2.

\section{Insert Figure 2. Mediator effect of organizational ambidexterity}

The increase in $\mathrm{R}^{2}$ from Model 1 to Model is 0.12 . Effect importance $\left(f^{2}\right)^{\mathrm{i}}$ was calculated so that $f^{2}$ levels of $0.02,0.15$ and 0.35 could be observed as proof or indication of a small, medium or large effect caused by the mediator variable, respectively. Our conclusion was that the increase in $\mathrm{R}^{2}$ is significant, value $f^{2}=0.35$ which means that the model's explanatory increase is strong. Thus, the observation of Model 2 shows us that: a) variations in HR flexibility significantly affect mediator variable ambidexterity; b) variations in mediator variable ambidexterity significantly impact on dependent variable performance; and c) the previously significant relationship between HR flexibility and performance (that of Model 1) stops being significant when the mediator variable is introduced (Model 2).

Since the procedure devised by Baron and Kenny (1986) provides no information whatsoever about the significance of indirect effects, a bootstrapping method is applied to find it (Preacher and Hayes, 2004). More precisely, a decision was made to apply the percentile method based on the works of authors such as Chin (2001) or Williams and MacKinnon (2008), which uses a bootstrapping method with 5,000 subsamples to calculate a confidence interval for the mediator effect with a 5\% confidence margin. Figure 2 shows that the value zero is not contained in the HR Flexibility $>$ Ambidexterity $>$ Performance path, which allows us to state that the previously calculated indirect effect is significant. This would in turn lead us to confirm Hypothesis 4. Organizational ambidexterity consequently 
behaves as a mediator variable between human resource flexibility and organizational performance. It is also a total mediation, insofar as the initially significant direct relationship (Model 1 Figure 2) loses its significance with the introduction of the mediator variable.

\section{Discussion}

This study examines the proposition that HR flexibility facilitates the development of organizational ambidexterity, which in turn has positive effects on firm performance. The findings provide partial support for this proposition. A full mediator effect of organizational ambidexterity on the relationship between HR flexibility and performance is found. However, it is not possible for us to show that such flexibility directly influences performance. This may be due to the fact that human resource flexibility has a gradual effect on the development of the organizational ambidexterity capability.

The results of this study contribute to the knowledge on the impact of human resource flexibility on performance. In fact, the studies on HR flexibility performed so far have focused on analysing the role played by this flexibility as a mediator variable between HPWS and performance -a total mediation effect being verified in most cases (Beltrán-Martín et al., 2008; Sawhney, 2013; Hui et al., 2010). This work goes one step further, examining the extent to which human resource flexibility (which will obviously depend on people management practices) influences the ability to undertake exploitation and exploration processes at the same time. Our paper thus stresses the strategic role that human resources play within organizations, insofar as their flexibility makes it possible to develop a highly relevant organizational capability such as ambidexterity.

The contribution made with this work in theoretical terms lies in the fact that it represents a step forward in the study field shaped by organizational ambidexterity and HR flexibility. The verification that flexibility in human resources is an antecedent factor of organizational 
ambidexterity provides a better understanding of which elements act as facilitators of this capability. From a 'micro' point of view, our work provides another factor to be taken into account within studies into organizational ambidexterity, thus complementing the extant bibliography, as suggested by Antonacopoulou, Guttel and Pesqueux (2010). Our results also support a key idea.in research on contextual ambidexterity: that ambidexterity has a close link with the efforts made by the organization to develop human resource flexibility (Cordey et al., 1993; Lepak et al., 2003). A further contribution is made to the new streams of research on human resource management which analyse the influence exerted by human resources on organizational capabilities (Collins and Smith, 2006; Wei and Lau, 2010; Chang et al., 2013; Patel et al., 2013; Prieto-Pastor and Martin-Perez, 2014).

The following practical implications stem from the present research work. Organizational ambidexterity arises as a key element in the generation of competitive advantages and, consequently, of competitiveness. The results obtained in this paper show that the capacity to simultaneously undertake exploitative and exploratory learning exerts a positive influence on performance. In the tourism industry as a whole -and more specifically in the hotel industryambidexterity is an essential capability for exploitation-based type learning which facilitates efficiency and competition via prices. Nevertheless, organizations must also cultivate innovation to cope with the changes that constantly occur in such a dynamic sector. This is why human resource managers must bear in mind the important role that HR flexibility development plays in this process.

These managers must, therefore, start employing functional flexibility formulas that contribute to business success more rigorously, not confining themselves to numerical flexibility (part-time jobs, subcontracting, etc.). This is a conception of HR flexibility that would be placed within the paradigm of organizational dynamic capabilities, which would facilitate the development of ambidextrous learning and, consequently, the organization's 
ability to be efficient, exploiting the knowledge that it owns together with the capacity to learn to adapt to the new demands imposed by the market. More precisely, a need would exist to encourage behavioural flexibility; that is, to develop employees' ability to adapt their responses and actions to any new circumstances which might arise in the workplace. This aim can only be fulfilled if the human resource management achieves an alignment of individual interests with strategic goals. This behavioural flexibility will be viable as long as skill flexibility is previously developed; in other words, employees need to be versatile in order to perform different tasks and/or functions, and they must also be given the opportunity to develop new skills in the future. Finally, the human resource management has to implement people management practices which can easily adapt to any potential organizational contingencies. In short, it would be necessary to adopt a strategic approach to human resource management based on the use of high performance work systems, the positive effect of which on functional flexibility has already been demonstrated in previous works (Beltrán-Martín et al., 2008).

The hotel industry has always shown a special concern for labour flexibility and its repercussions on productivity; although most studies have focused on numerical flexibility and its benefits (Lucas, 1995; Hoque, 2013; Yaduma et al., 2015). Adding the fact that a labour surplus exists in this industry, it comes as no surprise to find that numerical flexibility -along with the people management approach (Marco and Ubeda, 2013)- have traditionally been the formulas preferred by human resource management in this sector.

Nevertheless, the present paper highlights the fact that the development of functional flexibility in the terms described above will also cause an indirect impact on organizational performance through the development of organizational ambidexterity. Thus we confirm the results of previous papers that find a positive relationship between functional flexibility and performance (Ngo and Loi, 2008; Ketkar and Sett, 2009; Ngo, Loi and Foley, 2011; Tracey, 
2012; Chang et al., 2013; Way, Wright and Tracey, 2013; Preenen et al., 2015), with the qualification that this relationship is produced through the development of ambidextrous learning.

In addition to influencing performance, this approach to flexibility might prove more advantageous for firms, as shown by the outcomes of the study carried out by Kelliher and Riley (2010): greater job satisfaction amongst employees, better customer service, reduction of staff turnover, and improved firm reputation.

\section{Limitations and future research}

This research faced a number of limitations. The first is related to the analysis technique utilized -Partial Least Squares (PLS)- where linearity between latent variables is assumed. Moreover, the study deals with a single Spanish region and focuses on the hotel industry; to this can be added the small sample size, which must be considered for the interpretation of the results obtained. Also, the study does not consider any possible moderator variables in the relationships between HR flexibility-performance and ambidexterity-performance. In the first case, the bibliography on functional flexibility introduces the moderating effect of some variables such as: the dynamism of the environment (Tracey, 2012; Ketkar and Sett, 2012; Natasaputra and Kusumastuti, 2016) or inter-organizational cooperation (Vela-Jimenez, 2014). In the second case, apart from the dynamism of the environment (Jansen et al., 2006) a moderating effect has also been found in the ambidexterity-performance relationship of variables such as competitive intensity (Schulze et al., 2008), structural differentiation (Jansen et al., 2012), resource endowment (Venkatraman et al., 2007) or leadership type (Jansen et al., 2008).

These limitations represent new paths for the future development of work in this area. By way of example, the study could be geographically extended to cover the whole Spanish 
territory -even obtaining empirical evidence in other countries. It would equally be very interesting to have the chance of testing the same hypotheses in other activity sectors so that a comparison could be drawn between the respective results obtained. Future works might focus on analysing which HR flexibility component (skill flexibility; behavioural flexibility; or HR practice flexibility) has the strongest influence on the development of organizational ambidexterity, and even the indirect (mediation) effects which could exist between these three types of flexibility. Attention might also be paid in future studies to the impact of flexibility on results affecting other stakeholders (not focusing merely on economic results), including improved firm reputation, increased job satisfaction or higher degree of customer loyalty, amongst others. Finally, future studies could include the moderator variables (internal and external) referred to earlier to identify the extent to which these factors can influence the relationships analysed in this paper.

\section{References}

Aagaard A, Andersen T (2014) How can HR practices support front-end innovation and increase the innovativeness of companies? European Journal of International Management. 8(5): 488-505.

Ahammad FM, Mook Lee S, Malul M, Shoham A (2015) Behavioral Ambidexterity: The Impact of Incentive Schemes on Productivity, Motivation, and Performance of Employees in Commercial Banks. Human Resource Management. 54(S1): 45-62.

Antonacopoulou E, Guttel W, Pesqueux Y (2010) Practising socializing and institutionalizing. Society and Business Review. 5(2): 22-47.

Arthur, JB (1994) Effects of human resource systems on manufacturing performance and turnover. Academy of Management journal 37(3): 670-687.

Arulampalam W, Booth AL (1998) Training and labour market flexibility: is there a tradeoff? British Journal of Industrial Relations. 36(4): 521-536. 
Aryee S, Walumbwa FO, Seidu EY, Otaye L E (2016) Developing and Leveraging Human Capital Resource to Promote Service Quality Testing a Theory of Performance. Journal of management. 42(2): 480-499.

Atkinson J (1984) Manpower strategies for flexible organisations. Personnel management. 16(8): 28-31.

Atuahene-Gima, K (2005) Resolving the capability-rigidity paradox in new product innovation. Journal of marketing. 69(4): 61-83.

Bahramin H (1992) The Emerging Flexible Organization: Perspectives from Silicon Valley. California Management Review. 34(4): 33-52.

Barclay D, Higgins C, Thompson R (1995) The partial least squares (PLS) approach to causal modeling: Personal computer adoption and use as an illustration. Technology studies. 2(2): 285-309.

Baron RM, Kenny DA (1986) The moderator-mediator variable distinction in social psychological research: Conceptual, strategic, and statistical considerations. Journal of personality and social psychology. 51(6): 1173-1182.

Beltrán-Martín I, Roca-Puig V (2013) Promoting employee flexibility through HR practices. Human Resource Management. 52(5): 645-674.

Beltrán-Martín I, Roca-Puig V, Escrig-Tena A, Bou-Llusar JC (2008) Human resource flexibility as a mediating variable between high performance work systems and performance. Journal of Management. 34(5): 1009-1044.

Beltrán-Martín I, Roca-Puig V, Escrig-Tena A, Bou-Llusar JC (2009). Internal labor flexibility from a resource-based view approach: Definition and proposal of a measurement scale. International Journal of Human Resource Management. 20(7): 1576-1598.

Benner MJ, Tushman ML (2003) Exploitation, exploration, and process management: The productivity dilemma revisited. Academy of Management Review. 28(2): 238-256. 
Bhattacharya M, Gibson DE, Doty DH (2005) The effects of flexibility in employee skills, employee behaviors, and human resource practices on firm performance. Journal of Management. 31 (4): 622-640.

Birkinshaw J, Gupta K (2013) Clarifying the distinctive contribution of ambidexterity to the field of organization studies. The Academy of Management Perspectives, 27(4), 287-298.

Bock GW, Zmud RW, Kim YG, Lee JN (2005) Behavioral intention formation in knowledge sharing: Examining the roles of extrinsic motivators, social-psychological forces, and organizational climate. MIS quarterly. 29(1): 87-111.

Bowman EH, Hurry D (1993) Strategy through the Option Lens: An Integrated View of Resource Investments and the Incremental Choice Process. Academy of Management Review. 18(4): 760-782.

Boxall P (2013) Mutuality in the management of human resources: assessing the quality of alignment in employment relationships. Human Resource Management Journal. 23(1): 3-17. Boxall P, Steeneveld M (1999) Human resource strategy and competitive advantage: A longitudinal study of engineering consultancies. Journal of Management studies. 36(4): 443463.

Brown JR, Dev CS (1999) Looking beyond RevPAR: productivity consequences of hotel strategies. The Cornell Hotel and Restaurant Administration Quarterly. 40(2): 23-33.

Camelo C, Martín F, Romero PM, Valle R (2004) Human resources management in Spain: Is it possible to speak of a typical model? International Journal of Human Resource Management.15(6): 935-958.

Camps J, Oltra V, Aldás-Manzano J, Buenaventura-Vera G, Torres-Carballo F (2015) Individual Performance in Turbulent Environments: The Role of Organizational Learning Capability and Employee Flexibility. Human Resource Management. 
Cao Q, Gedajlovic E, Zhang H (2009) Unpacking organizational ambidexterity: Dimensions, contingencies, and synergistic effects. Organization Science. 20(4): 781-796.

Carmines EG, Zeller, RA (1979) Reliabilitv and validitv assessment. Sage publications. Beverly Hills, CA.

Caspin-Wagner K, Ellis S, Tishler A (2012) Balancing exploration and exploitation for firm's superior performance: The role of the environment. In annual meetings of the Academy of Management.

Chang S, Gong Y, Way SA, Jia L (2013) Flexibility-oriented HRM systems, absorptive capacity, and market responsiveness and firm innovativeness. Journal of Management. 39(7): 1924-1951.

Chang YY, Hughes M (2012) Drivers of innovation ambidexterity in small-to medium-sized firms. European Management Journal. 30(1): 1-17.

Chang YY, Hughes M, Hotho S (2011) Internal and external antecedents of SMEs' innovation ambidexterity outcomes. Management Decision. 49(10): 1658-1676.

Chebbi H, Yahiaoui D, Vrontis D, Thrassou A (2015) Building Multiunit Ambidextrous Organizations-A Transformative Framework. Human Resource Management. 54(S1): 155177.

Chin WW (1998) The partial least squares approach to structural equation modeling. Modern methods for business research. 295(2): 295-336.

Chin WW, Marcolin BL, Newsted PR (2003) A partial least squares latent variable modeling approach for measuring interaction effects: Results from a Monte Carlo simulation study and an electronic-mail emotion/adoption study. Information Svstems Research. 14(2): 189-217. Collins CJ, Smith KG (2006) Knowledge exchange and combination: The role of human resource practices in the performance of high-technology firms. Academy of Management Journal 49(3): 544-560. 
Cordery J, Sevastos P, Mueller W, Parker S (1993) Correlates of employee attitudes toward functional flexibility. Human Relations. 46(6): 705- 723.

Crant JM (1995) The Proactive Personality Scale and objective job performance among real estate agents. Journal of Applied Psychology. 80(4): 532.

De Lastra S F P, Martin-Alcazar F, Sanchez-Gardey G (2014) Functional Flexibility in Human Resource Management Systems: Conceptualization and Measurement. International Journal of Business Administration. 5(1):1

Duncan T, Scott DG, Baum T (2013) The mobilities of hospitality work: An exploration of issues and debates. Annals of Tourism Research. 41: 1-19.

Eisenhardt KM, Martin JA (2000) Dynamic Capabilities: What are They? Strategic Management Journal. 21(10-11): 1105-1121.

Ericksen J, Dyer L (2005) Toward a strategic human resource management model of high reliability organization performance. The international journal of human resource management 16(6): 907-928.

Falk RF, Miller NB (1992) A primer for soft modeling. University of Akron Press.

Floyd S, Lane P (2000) Strategizing throughout the organization: Managing role conflict in strategic renewal. Academy of Management Review. 25(1): 154-177.

Forés B, Camisón C (2016) Does incremental and radical innovation performance depend on different types of knowledge accumulation capabilities and organizational size? Journal of Business Research. 69(2): 831-848.

Fu N, Flood PC, Bosak J, Rousseau, DM, Morris, T, O'Regan P (2015) High-Performance Work Systems in Professional Service Firms: Examining the Practices-Resources-UsesPerformance Linkage. Human Resource Management. Doi:10.1002/hrm.21767 
Gedajlovic E, Cao Q, Zhang H (2012) Corporate shareholdings and organizational ambidexterity in high-tech SMEs: Evidence from a transitional economy. Journal of Business Venturing. 27(6): 652-665.

Geerts, Annalies, Blindenbach-Driessen, Floortje, Gemmel, Paul (2010). Achieving a balance between exploration and exploitation in service firms: A Longitudinal study. Paper presented at the annual meetings of the Academy of Management.

Gibson CB, Birkinshaw J (2004) The antecedents, consequences and mediating role of organizational ambidexterity. Academv Management Journal. 47: 209-226.

Glaister KW, Ahammad MF, Junni P (2015) Special issue of International Journal of Human Resource Management: Organizational ambidexterity and human resource practices. The International Journal of Human Resource Management. 26(13): 1785-1789.

Glaser, L, Stam, W, Takeuchi R (2015) Managing the risks of proactivity: A multilevel study of initiative and performance in the middle management context. Academy of Management Journal. Doi 10.5465/amj.2014.0177

Guerrier Y, Lockwood A (1989) Core and peripheral employees in hotel operations. Personnel Review. 18(1): 9-15.

Gupta AK, Smith KG, Shalley CE (2006). The interplay between exploration and exploitation. Academy of Management Journal.49: 693-706.

Hahn T, Pinkse J, Preuss L, Figge F (2016) Ambidexterity for corporate social performance. Organization Studies. 37(2): 213-235.

Hair JF, Ringle CM, Sarstedt M (2011) PLS-SEM: Indeed a silver bullet. Journal of Marketing Theory and Practice. 19(2): 139-152.

Hannan MT, Freeman J (1989) Organizational Ecology,Harvard, Cambridge, MA.

He ZL, Wong PK (2004) Exploration vs. exploitation: An empirical test of the ambidexterity hypothesis. Organization Science. 15(4): 481-494. 
Hitt M A, Biermant L, Shimizu K, Kochhar R (2001) Direct and moderating effects of human capital on strategy and performance in professional service firms: A resource-based perspective. Academy of Management Journal. 44(1): 13-28.

Hitt M A, Keats BW, DeMarie SM (1998) Navigating in the New Competitive Landscape: Building Strategic Flexibility and Competitive Advantage in the twenty first century. Academy of Management Executive. 4: 23-42.

Hoque K (2013) Human resource management in the hotel industry: Strategy, innovation and performance. Routledge.

Hui X, Su-ying G, Yan-li Z, Jin Z (2010) The correlations between high performance work systems, human resource flexibility and organizational performance. In Management Science and Engineering (ICMSE), 2010 International Conference on (pp. 989-995). IEEE.

Ismail A, Zaidi MF, Anuar A (2015) Administrator'S Role In Performance Based Reward As A Determinant of Employee Outcomes. Management and Marketing Journal. 13(1): 92-110. Jansen JJ, Tempelaar M, Van Den Bosch FA, Volberda H (2009) Structural differentiation and ambidexterity: The mediating role of integration mechanisms. Organization Science. 20 (4): 797-811.

Jansen JJ, Van Den Bosch FA, Volberda HW (2006) Exploratory innovation, exploitative innovation, and performance: Effects of organizational antecedents and environmental moderators. Management Science. 52(11): 1661-1674.

Jansen JJ, Volberda HW, Van Den Bosch FA (2005) Exploratory innovation, exploitative innovation, and ambidexterity: The impact of environmental and organizational antecedents. Schmalenbach Business Review. 57: 351-363.

Jerez-Gomez P, Cespedes-Lorente J, Valle-Cabrera R (2005) Organizational learning capability: a proposal of measurement. Journal of business research. 58(6): 715-725. 
Kalleberg AL (2001) Organizing flexibility: the flexible firm in a new century. British Journal of Industrial Relations. 39(4): 479-504.

Kalleberg, AL (2003) Flexible firms and labor market segmentation effects of workplace restructuring on jobs and workers. Work and Occupations. 30(2): 154-175.

Kang SC, Snell SA, Swart J (2012) Options-based HRM, intellectual capital, and exploratory and exploitative learning in law firms' practice groups. Human Resource Management. 51(4): $461-485$

Kelliher C, Riley M (2003) Beyond efficiency: some by-products of functional flexibility. The Service Industries Journal. 23(4): 98-113.

Kerr JL, Jackofsky EF (1989) Aligning managers with strategies: Management development versus selection. Strategic Management Journal. 10(1):157-170.

Ketkar S, Sett PK (2010) Environmental dynamism, human resource flexibility, and firm performance: analysis of a multi-level causal model. International Journal of Human Resource Management. 21(8): 1173-1206.

Ketkar S, Sett PK (2009) HR flexibility and firm performance: analysis of a multi-level causal model. International Journal of Human Resource Management. 20(5): 1009-38.

Khatri N (2000) Managing human resource for competitive advantage: a study of companies in Singapore. International Journal of Human Resource Management. 11(2): 336-365.

Kirkman B L, Rosen B (1999) Beyond self-management: Antecedents and consequences of team empowerment. Academy of Management Journal. 42(1): 58-74.

Klingebiel R, Adner R (2015) Real options logic revisited: the performance effects of alternative resource allocation regimes. Academy of Management Journal. 58(1): 221-241.

Knox A, Walsh J (2005) Organisational flexibility and HRM in the hotel industry: evidence from Australia. Human Resource Management Journal. 15(1): 57-75. 
Kogut B, Kulatilaka N (2001). Capabilities as Real Options. Organization Science. 12(6): 744-758.

Kohli AK, Shervani TA, Challagalla GN (1998) Learning and performance orientation of salespeople: The role of supervisors. Journal of Marketing Research. 35(2): 263-274.

Kok RA, Ligthart PE (2014) Differentiating Major and Incremental New Product Development: The Effects of Functional and Numerical Workforce Flexibility. Journal of Product Innovation Management. 31(1): 30-42.

Kumari IG, Pradhan RK Human Resource Flexibility and Organizational Effectiveness: Role of Organizational Citizenship Behaviour and Employee Intent to Stay. International Journal of Business and Management Invention. 3 (11): 43-51.

Lado A A, Wilson MC (1994) Human resource systems and sustained competitive advantage: A competency-based perspective. Academy of Management Review. 19(4): 699-727.

Lavie D, Kang J, Rosenkopf L (2011) Balance within and across domains: The performance implications of exploration and exploitation in alliances. Organization Science. 22(6): 15171538.

Leiblein, M.J. 2003. The Choice of Organizational Governance Form and Performance: Predictions from Transaction Cost, Resource-based, and Real Options Theories. Journal of Management, 29(6): 937-961.

Lengnick-Hall CA, Lengnick-Hall ML (1988) Strategic human resources management: A review of the literature and a proposed typology. Academy of Management Review. 13(3): 454-470.

Lepak DP, Takeuchi R, Snell S (2003) Employment flexibility and firm performance: Examining the interaction effects of employment mode, environmental dynamism, and technological intensity. Journal of Management. 29(5): 681-703. 
LePine JA, Colquitt JA, Erez, A (2000) Adaptability to changing task contexts: Effects of general cognitive ability, conscientiousness, and openness to experience. Personnel Psychology. 53(3): 563-593.

Lin Z, Yang H, Demirkan I (2007) The performance consequences of ambidexterity in strategic alliance formations: Empirical investigation and computational theorizing. Management Science. 53(10): 1645-1658.

López-Cabrales Á, Real JC, Valle R (2011) Relationships between human resource Management practices and organizational learning capability: The mediating role of human capital. Personnel Review. 40(3): 344-363.

Lubatkin MH, Simsek Z, Ling Y, Veiga JF (2006) Ambidexterity and performance in smallto medium-sized firms: The pivotal role of top management team behavioral integration. Journal of management. 32(5): 646-672.

Lucas RE (1995) Managing employee relations in the hotel and catering industry. Cassell plc.

MacDuffie JP (1995) Human resource bundles and manufacturing performance: Organizational logic and flexible production systems in the world auto industry. Industrial \& Labor Relations Review. 48(2): 197-221.

March JG (1991) Exploration and exploitation in organizational learning. Organization Science. 2: 71-87.

Martín IB, Tena ABE, Llusar JCB, Puig VR (2013) Influencia de las prácticas de recursos humanos en la flexibilidad de los empleados. Cuadernos de Economía y Dirección de la Empresa. 16(4): 221-237.

Maurer TJ, Wrenn KA, Pierce HR, Tross SA, Collins WC (2003) Beliefs about 'improvability' of career-relevant skills: relevance to job/task analysis, competency modelling, and learning orientation. Journal of Organizational Behavior. 24(1): 107-131. 
McGrath RG, Ferrier WJ, Mendelow AL (2004) Response: Real Options as Engines of Choice and Heterogeneity. Academy of Management Review. 29(1): 86-101

Michie J, Sheehan M (2005) Business strategy, human resources, labour market flexibility and competitive advantage. International Journal of Human Resource Management. 16(3): $445-464$.

Milkovich GT, Newman JM, Milkovich C (1999) Compensation. T. Mirror (Ed.). Burr Ridge, Ill.: Irwin/McGraw-Hill.

Milliman J, Von Glinow MA, Nathan M (1991) Organizational life cycles and strategic international human resource management in multinational companies: Implications for congruence theory. Academy of Management Review. 16(2): 318-339.

Mom TJ, Fourné SP, Jansen JJ (2015) Managers' work experience, ambidexterity, and performance: The contingency role of the work context. Human Resource Management. 54(1):133-153.

Mom TJ, Van Den Bosch FA, Volberda HW (2009) Understanding variation in managers' ambidexterity: Investigating direct and interaction effects of formal structural and personal coordination mechanisms. Organization Science. 20(4): 812-828.

Natasaputra N, Kusumastuti RD (2016) The Effect of Labor Flexibility on Firm Performance in Indonesian Telecommunication Industry. International Research Journal of Business Studies. 7(2):79-90

Ngo HY, Loi R (2008) Human resource flexibility, organizational culture and firm performance: An investigation of multinational firms in Hong Kong. International Journal of Human Resource Management. 19(9): 1654-1666.

Ngo HY, Turban D, Lau CM, Lui SY (1998) Human practices and firm performance of multinational corporations: influences of country of origin. International Journal of Human Resource Management. 9(4): 632-652. 
Nieves J, Quintana A (2016) Human resource practices and innovation in the hotel industry: The mediating role of human capital. Tourism and Hospitality Research. Doi 1467358415624137.

Patel PC, Messersmith JG, Lepak DP (2013) Walking the tightrope: An assessment of the relationship between high-performance work systems and organizational ambidexterity. Academy of Management Journal. 56(5): 1420- 1442.

Pfeffer J (1994) Competitive advantage through people. California Management Review. 36(2): 9 .

Pine R, Phillips P (2005) Performance comparisons of hotels in China. International Journal of Hospitalitu Management 24(1): 57-73.

Podsakoff PM, MacKenzie SB, Podsakoff NP (2012) Sources of method bias in social science research and recommendations on how to control it. Annual Review of Psychology. 65: 539-569.

Preacher K J, Hayes AF (2004) SPSS and SAS procedures for estimating indirect effects in simple mediation models. Behavior Research Methods, Instruments, \& Computers. 36(4): $717-731$

Prieto IM, Pérez Santana M (2012) Building ambidexterity: The role of human resource practices in the performance of firms from Spain. Human Resource Management. 51(2): 189211.

Prieto-Pastor I, Martin-Perez V (2014) Does HRM generate ambidextrous employees for ambidextrous learning? The moderating role of management support. International Journal of Human Resource Management. 21(13): 2452-2467.

Pulakos ED, Arad S, Donovan MA, Plamondon KE (2000) Adaptability in the workplace: development of a taxonomy of adaptive performance. Journal of Applied Psychology. 85(4): $612-624$ 
Raisch S, Birkinshaw J (2008) Organizational ambidexterity: Antecedents, outcomes, and moderators. Journal of Management. 34(3): 375-409.

Riley M, Lockwood A (1997) Strategies and measurement for workforce flexibility: an application of functional flexibility in a service setting. International Journal of Operations \& Production Management. 17(4): 413-419.

Rönnmar M (2004) The managerial prerogative and the employee's duty to work: a comparative study of functional flexibility in working life. International Journal of Human Resource Management. 15(3): 451-458.

Sanchez R (1995) Strategic flexibility in product competition. Strategic Management Journal. 16(1): 135-159.

Sanders K, Shipton H, Gomes JF (2014) Guest Editors' Introduction: Is the HRM Process Important? Past, Current, and Future Challenges. Human Resource Management. 53(4): 489503.

Sawhney R (2013) Implementing labor flexibility: A missing link between acquired labor flexibility and plant performance. Journal of Operations Management. 31(1): 98-108.

Schulze P, Heinemann F, Abedin A (2008) Balancing exploitation and exploration: Organizational antecedents and performance of ambidexterity. Best paper proceedings of the Academy of Management Annual Meeting, Anaheim, CA, 1-6.

Seibert SE, Crant JM, Kraimer ML (1999) Proactive personality and career success. Journal of Applied Psychology. 84(3): 416.

Sekhar C, Patwardhan M, Vyas V (2016) A Study of HR Flexibility and Firm Performance: A Perspective from IT Industry. Global Journal of Flexible Systems Management. 17(1): 5775 . 
Shaffer M A, Harrison DA, Gilley KM, Luk DM (2001). Struggling for balance amid turbulence on international assignments: work-family conflict, support and commitment. Journal of Management. 27(1): 99-121.

Simsek Z, Heavey C, Veiga JF, Souder D (2009) A typology for aligning organizational ambidexterity's conceptualizations, antecedents, and outcomes. Journal of Management Studies. 46(5): 864-894.

Sirmon DG, Hitt MA, Ireland RD (2007) Managing firm resources in dynamic environments to create value: Looking inside the black box. Academy of Management Review. 32(1): 273292.

Snape E, Redman T (2010) HRM Practices, Organizational Citizenship Behaviour, and Performance: A Multi-Level Analysis. Journal of Management Studies. 47(7): 1219-1247.

Snell SA, Youndt MA, Wright PM (1996) Establishing a framework for research in strategic human resource management: Merging resource theory and organizational learning. Research in Personnel and Human Resources Management. 14: 61-90.

Stettner U, Lavie D (2014) Ambidexterity under scrutiny: Exploration and exploitation via internal organization, alliances, and acquisitions. Strategic Management Journal.35(13): 1903-1929.

Stokes P, Moore N, Moss D, Mathews M, Smith SM, Liu Y (2015) The Micro-Dynamics of Intraorganizational and Individual Behavior and Their Role in Organizational Ambidexterity Boundaries. Human Resource Management. 54(1): 63-86.

Sujan H, Weitz BA, Kumar N (1994) Learning, orientation, working smart, and effective selling. Journal of Marketing. 58(3): 39-52.

Teece DJ (2007) Explicating Dynamic Capabilities: The Nature and Microfoundations of (Sustainable) Enterprise Performance. Strategic Management Journal. 28 (13): 1319-1350. 
Teece DJ, Pisano G, Shuen A (1997) Dynamic capabilities and strategic management. Strategic Management Journal. 18 (7): 509-533.

Tracey JB (2012) A contextual, flexibility-based model of the HR-firm performance relationship. Management Decision. 50(5): 909-924.

Trigeorgis L(1996). Real Options: Managerial Flexibility and Strategy in Resource Allocation, Cambridge, MA: MIT Press.

Turner N, Swart J, Maylor H (2013) Mechanisms for managing ambidexterity: a review and research agenda. International Journal of Management Reviews. 15(3): 317-332.

Tushman ML, Romanelli E (1985) Organizational evolution: Interactions between external and emergent processes and strategic choice. Research in Organizational Behavior. 8: 171222.

Van den Berg PT, Van der Velde ME (2005) Relationships of functional flexibility with individual and work factors. Journal of Business and Psychology. 20(1): 111-129.

Vela-Jiménez MJ, Martínez-Sánchez Á, Pérez-Pérez M, Abella-Garcés S (2014) How environmental changes and cooperation moderate labour flexibility and firm performance? Personnel Review. 43(6): 915-936.

Venkatraman N, Lee CH, Iyer B (2007) Strategic ambidexterity and sales growth: A longitudinal test in the software sector In Unpublished Manuscript (earlier version presented at the Academy of Management Meetings, 2005).

Volberda HW (1998) Building the flexible firm: How to remain competitive. Corporate Reputation Review. 2(1): 94-96.

Wang CL, Rafiq M (2014) Ambidextrous Organizational Culture, Contextual Ambidexterity and New Product Innovation: A Comparative Study of UK and Chinese High-tech Firms. British Journal of Management. 25(1): 58-76. 
Way SA, Wright PM, Tracey JB (2013) HR Flexibility and Firm Performance: The CrossLevel Moderating Effect of Industry Dynamism. In Academy of Management Proceedings.1. Wei LQ, Lau CM (2010) High performance work systems and performance: The role of adaptive capability. Human Relations. 63(10): 1487-1511.

Wei Z, Zhao J, Zhang C (2014) Organizational ambidexterity, market orientation, and firm performance. Journal of Engineering and Technology Management. 33: 134-153.

Williams J, MacKinnon DP (2008) Resampling and distribution of the product methods for testing indirect effects in complex models. Structural Equation Modeling. 15(1): 23-51.

Winter SG (2003) Understanding Dynamic Capabilities. Strategic Management Journal. 24(10): 991-995.

Wright PM, Dunford BB, Snell SA (2001) Human resources and the resource based view of the firm. Journal of Management. 27(6): 701-721.

Wright PM, McMahan GC, McWilliams A (1994) Human resources and sustained competitive advantage: a resource-based perspective. International Journal of Human Resource Management. 5(2): 301-326.

Wright PM, Snell SA (1998) Toward a unifying framework for exploring fit and flexibility in strategic human resource management. Academy of Management Review. 23(4): 756-772.

Yaduma N, Williams A, Lockwood A, Park S (2015) Performance, labour flexibility and migrant workers in hotels: An establishment and departmental level analysis. International Journal of Hospitality Management. 50: 94-104.

Yang TT, Li CR (2011) Competence exploration and exploitation in new product development: the moderating effects of environmental dynamism and competitiveness. Management Decision. 49(9): 1444-1470.

Youndt M A, Snell SA (2004) Human resource configurations, intellectual capital, and organizational performance. Journal of Managerial Issues. 16 (3): 337-360. 
Zimmermann A, Raisch S, Birkinshaw J (2015) How is Ambidexterity initiated? The

Emergent Charter Definition Process. Organization Science. 26(4): 1119-1139.

\section{Appendix 1}

\begin{tabular}{|c|c|}
\hline Human Resource Flexibility & References \\
\hline $\begin{array}{l}\text { Behavioral Flexibility ( } 1=I \text { totally disagree; } 4=I \text { neither agree nor disagree; } 7=I \text { totally } \\
\text { agree) } \\
\text { BF1 The flexibility of our employees' work habits helps us change according to market } \\
\text { demands. } \\
\text { BF2 People in our firm change their work habits in response to changes within the } \\
\text { competitive environment. } \\
\text { BF3 Our employees respond to changing situations within a short period. } \\
\text { BF4 People in our firm readily change their work habits as demanded by changes within } \\
\text { the working environment. } \\
\text { BF5 Most of our employees are flexible enough to adapt to dynamic work requirements. } \\
\text { BF6 Our employees adapt to changing work requirements within a short period. } \\
\text { BF7 Our employees' response to the changing nature of their jobs helps us remain } \\
\text { competitive in the market. } \\
\text { BF8 People in our firm change their behavior in response to customers' requirements. }\end{array}$ & $\begin{array}{l}\text { Verdú (1992) } \\
\text { Volverda (1998) } \\
\text { Bhattacharya et al. } \\
(2005) \\
\text { Beltran-Martín et al. } \\
(2008) \\
\text { Ketkar and Sett } \\
(2009) \\
\text { Beltran-Martin and } \\
\text { Roca-Puig (2013). }\end{array}$ \\
\hline $\begin{array}{l}\text { Skill Flexibility ( } 1=\mathrm{I} \text { totally disagree; } 4=\mathrm{I} \text { neither agree nor disagree; } 7=\mathrm{I} \text { totally agree) } \\
\text { SF1 Our firm can shift employees to different jobs when necessary. } \\
\text { SF2 Our employees can switch to new jobs in our company within a short period. } \\
\text { SF3 Our employees are capable of putting new skills to use within a short period. } \\
\text { SF4 Our firm is capable of meeting the demand(s) for new skills by retraining or } \\
\text { shifting its existing employees. } \\
\text { SF5 We employ people who own a broad variety of skills. } \\
\text { SF6 Many employees in our firm have multiple skills that are used in various jobs. } \\
\text { SF7 People in our firm can learn new skills within a short period. }\end{array}$ & $\begin{array}{l}\text { Verdú (1992) } \\
\text { Volverda (1998) } \\
\text { Bhattacharya et al. } \\
(2005) \\
\text { Beltran-Martín et al. } \\
(2008) \\
\text { Ketkar and Sett } \\
(2009) \\
\text { Beltran-Martin and } \\
\text { Roca-Puig (2013). }\end{array}$ \\
\hline $\begin{array}{l}\text { Human Resource Practices Flexibility ( } 1=\mathrm{I} \text { totally disagree; } 4=\mathrm{I} \text { neither agree nor } \\
\text { disagree; } 7=\mathrm{I} \text { totally agree) } \\
\text { PF1 The flexibility of our HR practices helps us adapt to the changing demands of the } \\
\text { business environment. } \\
\text { PF2 Our firm modifies its HR system to keep pace with the changing competitive } \\
\text { environment. } \\
\text { PF3 Our HR practice parameters have been designed in such a way that they can quickly } \\
\text { adapt to changes in business conditions. } \\
\text { PF4 We introduce frequent changes in our HR practices in order to align the HR system } \\
\text { with the changing work requirements. } \\
\text { PF5 Changes in our HR practices enable us to remain competitive in the market. } \\
\text { PF6 Our HR practices meaningfully adapt to changed business scenarios. } \\
\text { PF7 As a whole, our HR practices are flexible. }\end{array}$ & $\begin{array}{l}\text { Verdú (1992) } \\
\text { Volverda (1998) } \\
\text { Bhattacharya et al. } \\
(2005) \\
\text { Beltran-Martín et al. } \\
(2008) \\
\text { Ketkar and Sett } \\
(2009) \\
\text { Beltran-Martin and } \\
\text { Roca-Puig (2013). }\end{array}$ \\
\hline $\begin{array}{l}\text { Organizational Ambidexterity } \\
\text { Exploitative Innovation (1=I totally disagree; } 4=\text { I neither agree nor disagree; } 7=\mathrm{I} \\
\text { totally agree) } \\
\text { Exploitative1 We frequently carry out small adjustments in our existing products and } \\
\text { services } \\
\text { Exploitative2 We improve efficiency in our product and service provision } \\
\text { Exploitative3 We increase economies of scales in existing markets } \\
\text { Exploitative4 Our organization expands services for existing clients }\end{array}$ & $\begin{array}{l}\text { Jansen et al. (2006) } \\
\text { Jansen et al. (2009) } \\
\text { Stettner and Lavie } \\
(2014)\end{array}$ \\
\hline
\end{tabular}




\section{Exploratory Innovation ( $1=\mathrm{I}$ totally disagree; 4=I neither agree nor disagree; 7=I} totally agree)

Exploratory1 Our organization accepts demands that go beyond the existing products and services

Exploratory2 We commercialize products and services that are completely new to our organization

Exploratory3 We frequently take advantage of new opportunities in new markets Exploratory4 Our organization regularly uses new distribution channels

Performance $(1=$ much worse $; 4=$ the same; $7=$ much better $)$

P1 The growth in my firm's market share relative to competitors during the last three years has been...

P2 My firm's brand recognition relative to competitors during the last three years has been...

P3 My firm's image relative to competitors during the last three years has been...

$\mathrm{P} 4$ The average growth in my firm's sales relative to competitors during the last three years has been...

P5 My hotel's average occupancy relative to competitors during the last three years has been...

P6 Customers' satisfaction level relative to competitors during the last three years has been...

P7 Employees' satisfaction level relative to competitors during the last three years has been...

P8 Revenues per room in my hotel relative to competitors during the last three years has been...

$$
{ }^{\mathrm{i}} f^{2}=\frac{R_{\text {included }}^{2}-R_{\text {excluded }}^{2}}{1-R_{\text {included }}^{2}}
$$


Figure 1. Structural model results

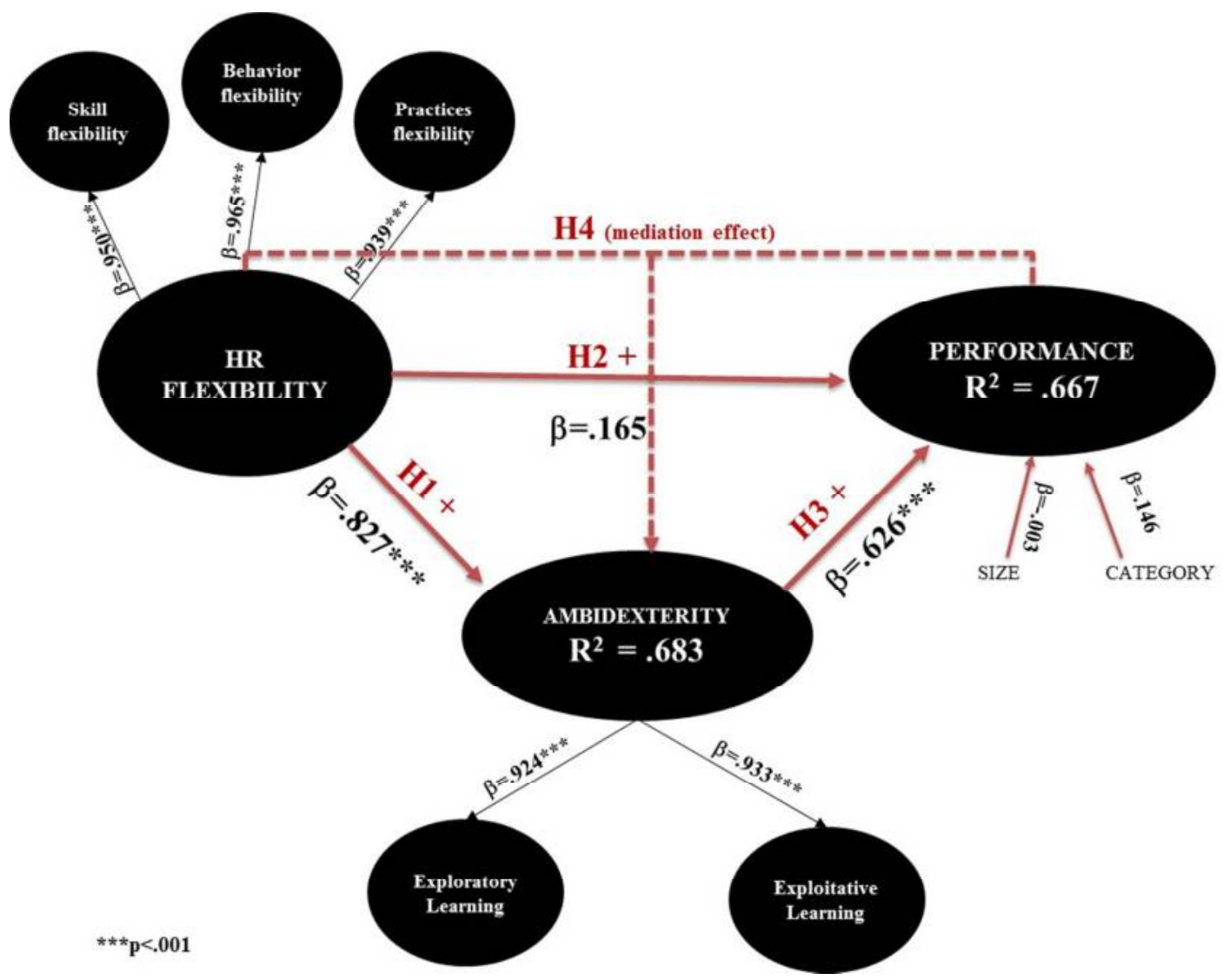

(c) Emerald Group Publishing Limited

This is a pre-print of a paper and is subject to change before publication. This pre-print is made available with the understanding that it will not be reproduced or stored in a retrieval system without the permission of Emerald Group Publishing Limited. 
Figure 2. Mediator effect of organizational ambidexterity

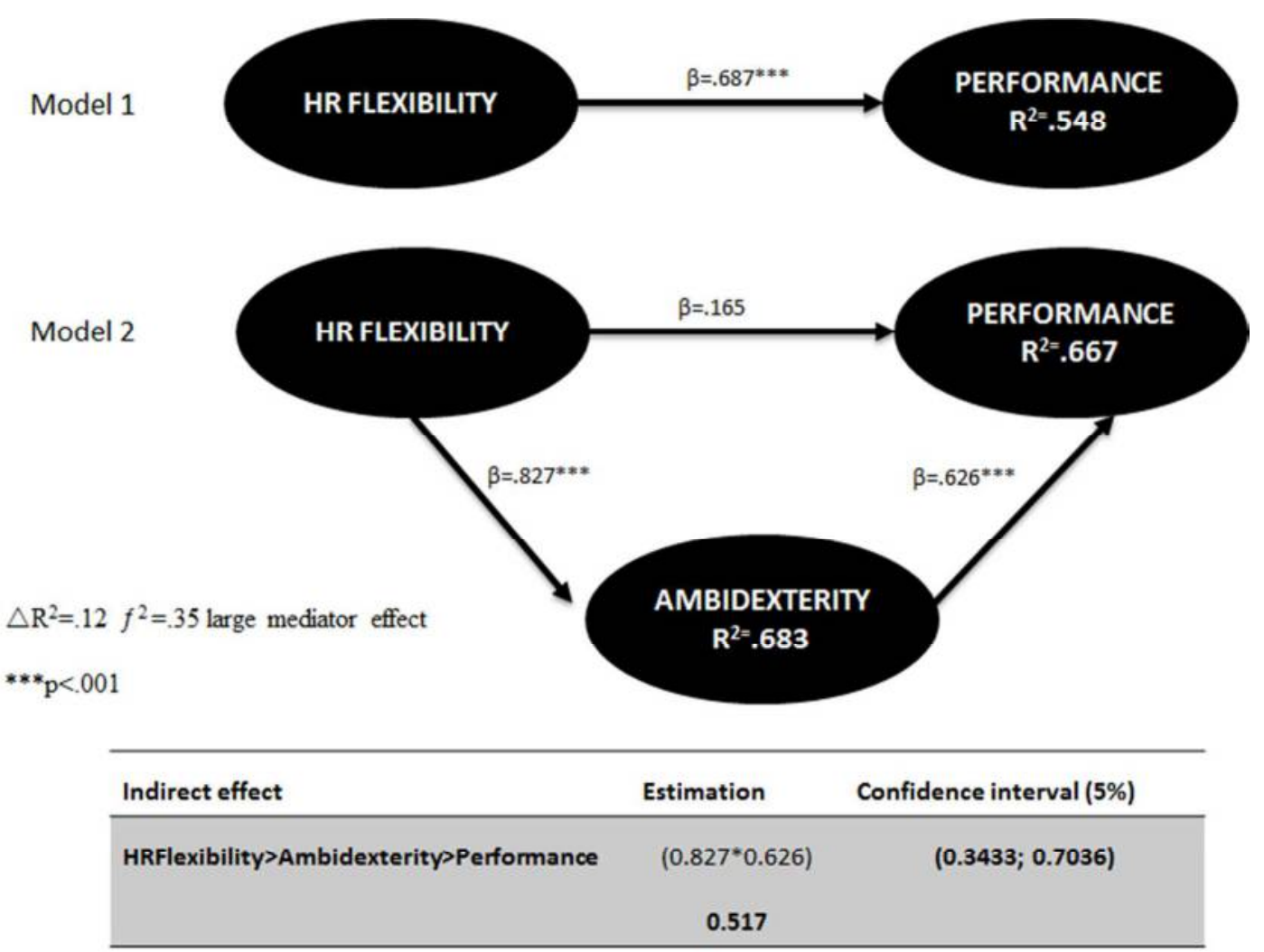

(c) Emerald Group Publishing Limited

This is a pre-print of a paper and is subject to change before publication. This pre-print is made available with the understanding that it will not be reproduced or stored in a retrieval system without the permission of Emerald Group Publishing Limited. 
Table 1. Measurement model evaluation

\begin{tabular}{|c|c|c|c|c|c|}
\hline Constructs & $\begin{array}{c}\alpha \\
\text { Cronbach }\end{array}$ & $\begin{array}{c}\text { Loading } \\
(\lambda)\end{array}$ & T value & $\begin{array}{l}\text { Composite } \\
\text { Reliability }\end{array}$ & $(\mathrm{AVE})$ \\
\hline HR FLEXIBILITY & 0.948 & & & 0.966 & 0.906 \\
\hline Skill flexibility & 0.938 & 0.950 & 71.766 & 0.950 & 0.732 \\
\hline Behavioral flexibility & 0.972 & 0.965 & 136.413 & 0.976 & 0.838 \\
\hline Practices flexibility & 0.976 & 0.939 & 69.880 & 0.980 & 0.875 \\
\hline AMBIDEXTERITY & 0.862 & & & 0.926 & 0.862 \\
\hline $\begin{array}{l}\text { Exploratory } \\
\text { Innovation }\end{array}$ & 0.768 & 0.924 & 47.482 & 0.852 & 0.594 \\
\hline $\begin{array}{l}\text { Exploitative } \\
\text { Innovation }\end{array}$ & 0.892 & 0.933 & 69.609 & 0.926 & 0.759 \\
\hline PERFORMANCE & 0.959 & & & 0.965 & 0.776 \\
\hline
\end{tabular}


Table 2. Measuring instrument: discriminant validity

\begin{tabular}{|l|l|l|l|}
\hline & AMBIDEXTERITY & HR FLEXIBILITY & PERFORMANCE \\
\hline AMBIDEXTERITY & $\mathbf{0 . 9 2 8}$ & & \\
\hline HR FLEXIBILITY & 0.826 & $\mathbf{0 . 9 5 1}$ & \\
\hline PERFORMANCE & 0.796 & 0.722 & $\mathbf{0 . 8 8 2}$ \\
\hline
\end{tabular}


Table 3. Hypothesis confirmation

\begin{tabular}{|c|c|c|c|c|}
\hline Hypothesis & $\begin{array}{c}\text { Suggested } \\
\text { effect }\end{array}$ & $\begin{array}{c}\text { Path } \\
\text { coefficients }\end{array}$ & $\begin{array}{c}\text { t-value } \\
\text { (bootstrap) }\end{array}$ & Support \\
\hline $\begin{array}{l}\text { H1: HR FLEXIBILITY> } \\
\text { AMBIDEXTERITY }\end{array}$ & + & 0.827 & $30.061 * * *$ & Yes \\
\hline $\begin{array}{l}\text { H2: HR FLEXIBILITY> } \\
\text { PERFORMANCE }\end{array}$ & + & 0.165 & 1.398 & No \\
\hline $\begin{array}{l}\text { H3: AMBIDEXTERITY> } \\
\text { PERFORMANCE }\end{array}$ & + & 0.626 & $6.035 * * *$ & Yes \\
\hline CATEGORY $>$ PERFORMANCE & & 0.146 & 1.951 & No \\
\hline SIZE $>$ PERFORMANCE & & -0.003 & 0.049 & No \\
\hline
\end{tabular}


Table 4. Effects on endogenous variables

\begin{tabular}{|c|c|c|c|c|c|}
\hline & $\overline{\mathbf{R}^{2}}$ & $\overline{Q^{2}}$ & $\begin{array}{l}\text { Direct } \\
\text { effect }\end{array}$ & Correlation & $\begin{array}{l}\text { Variance } \\
\text { explained }\end{array}$ \\
\hline $\begin{array}{l}\text { AMBIDEXTERITY } \\
\text { FLEXIBILITY }\end{array}$ & 0.683 & 0.582 & 0.827 & 0.826 & $68.30 \%$ \\
\hline PERFORMANCE & 0.667 & 0.493 & & & \\
\hline AMBIDEXTERITY & & & 0.626 & 0.797 & $49.90 \%$ \\
\hline HR FLEXIBILITY & & & 0.165 & 0.722 & $11.91 \%$ \\
\hline SIZE & & & -0.003 & 0.125 & $-0.037 \%$ \\
\hline CATEGORY & & & 0.146 & 0.341 & $4.97 \%$ \\
\hline
\end{tabular}

